\title{
Liver transplantation normalizes serum hepcidin level and cures iron metabolism ALTERATIONS in HFE hemochromatosis
}

Short Title: Hemochromatis liver transplantation

Manuscript number : HEP-13-0526

Edouard Bardou-Jacquet ${ }^{1,2,5}$, Julie Philip ${ }^{1}$, Richard Lorho ${ }^{1,3}$, Martine Ropert ${ }^{4,5}$, Marianne Latournerie ${ }^{1}$, Pauline Houssel-Debry ${ }^{3}$, Dominique Guyader ${ }^{1,2}$, Olivier Loreal ${ }^{2,5}$, Karim Boudjema ${ }^{3,2}$, Pierre Brissot ${ }^{1,2,5}$

1. CHU Rennes, Liver Disease Unit, F-35033 Rennes, France.

2. INSERM UMR991, University of Rennes 1, F-35033, Rennes, France.

3. CHU Rennes, Hepato-biliary and digestive surgery unit, University hospital Pontchaillou, F-35033 Rennes, France.

4. CHU Rennes, Laboratory of Biochemistry, University hospital Pontchaillou, F-35033 Rennes, France.

5. CHU Rennes, National reference center for rare iron overload diseases of genetic origin, F-35033 Rennes, France

Keyword: iron overload, p.Cys282Tyr, 


\title{
Address for correspondence:
}

Edouard Bardou-Jacquet, MD, Service des maladies du foie, CHU Pontchaillou, 35033 Rennes, France - E mail : edouard.bardou-jacquet@chu-rennes.fr.

Phone: +33 2992842 97; FAX: +3329928 4112

\author{
Abbreviations \\ LT: Liver Transplantation \\ HCC: Hepatocellular Carcinoma \\ HCV: Hepatitis C virus \\ MRI: Magnetic Resonance Imaging \\ HH: HFE related Hemochromatosis \\ LIC: Liver iron concentration
}

Grant support: This study was supported by the Association Fer et Foie and The French National reference center for rare iron overload diseases of genetic origin.

Disclosure: Authors have no potential conflicts to disclose relevant to this manuscript

Writing assistance: This manuscript was edited for English by San Fransisco Edit, Mill Valley, CA 94941 USA. 


\section{ABSTRACT}

Background: Defects in human hemochromatosis protein (HFE) cause iron overload due to reduced hepatic hepcidin secretion. Liver transplantation (LT) is a key treatment for potential complications from HFE-related hereditary hemochromatosis $(\mathrm{HH})$. This study evaluated hepcidin secretion and iron burden after LT to elucidate HH pathophysiology. Methods: Patients ( $n=18)$ homozygous for the p.Cys282Tyr mutation in the HFE gene underwent LT between 1999 and 2008. Serum iron, serum hepcidin, and hepatic iron concentrations were determined before LT and at the end of follow-up (median 57 months). Mortality and causes of death were determined. Survival was compared to that of the overall patient population that received LT. Results: Before LT, serum hepcidin levels were low $(0.54 \pm 2.5 \mathrm{nmol} / \mathrm{L}$; normal range: $4-30 \mathrm{nmol} / \mathrm{L})$. After $\mathrm{LT}, 11$ patients had iron evaluations; none received iron depletion therapy; all had normal transferrin saturation. The mean serum ferritin was 185 ( \pm 99$) \mu \mathrm{g} / \mathrm{L}$. Magnetic resonance imaging showed that iron overload was absent in 9 patients, mild in one patient with metabolic syndrome, and high $(180 \mu \mathrm{mol} / \mathrm{g})$ in one patient with hereditary spherocytosis unmasked after liver transplantation. At the end of follow-up, serum hepcidin was normal in 10 patients (11.12 $\pm 7.6 \mathrm{nmol} / \mathrm{L} ; \mathrm{p}<0.05)$ and low in one patient with iron deficiency anemia. Survival was $83 \%$ and $67 \%$ at one and 5 years, respectively. Survival was similar for patients with $\mathrm{HH}$ and patients that received LT for other causes. Conclusion: This study demonstrated that, in HH, LT normalized hepcidin secretion and prevented recurrence of hepatic iron overload. Survival was similar to that of patients that received LTs for other liver diseases. 


\section{INTRODUCTION}

Since 1865, when Trousseau first described hemochromatosis and demonstrated its genetic nature (1), many studies have shed light on its putative pathophysiological mechanism. The most important breakthrough was the discovery of the gene that encoded human hemochromatosis protein (HFE). This made it possible to diagnose the most common form of hereditary hemochromatosis $(\mathrm{HH})(2)$, the p.Cys282Tyr mutation $(\mathrm{C} 282 \mathrm{Y})$ in the HFE gene. In addition, these discoveries enabled discrimination of HFE-related $\mathrm{HH}$ from various secondary causes of iron overload and other rare genetic entities(3). The underlying mechanism of HH was initially thought to be related to the role of HFE in regulating iron absorption at the intestinal crypt (4), which was supported by the observation that excessive iron absorption occurred in $\mathrm{HH}(5)$. However, this hypothesis has not been confirmed thereafter.

Another major breakthrough in understanding iron metabolism in $\mathrm{HH}$ was the discovery of hepcidin and its role in iron metabolism(6, 7). Mainly secreted by the liver, this small peptide was shown to interact with ferroportin, the only known cellular iron exporter, and this interaction induced ferroportin internalization and degradation(8). Through its regulation of ferroportin, hepcidin can reduce iron export from macrophages and enterocytes into the bloodstream. Consequently, the liver represents the major regulator of iron metabolism. In patients with $\mathrm{HH}$, serum hepcidin levels were shown to be inappropriately low (9).

The molecular impact of the HFE C282Y mutation has not been fully elucidated. It is thought to inhibit the ability of HFE to interact with $\beta 2$ microglobulin and transferrin receptor 1 (TFR1)(10). The interactions between HFE and TFR1 and TFR2 $(11,12)$ play important roles in iron sensing at the hepatocyte membrane, which regulates hepcidin expression. Mice with $\mathrm{Hfe}$ gene knock-outs display a hemochromatosis phenotype with inappropriately low hepcidin expression $(13,14)$. Mice with a liver-specific Hfe knock-out presented the same phenotype(15). Conversely, hepatic-specific expression of wild-type HFE in HFE knock-out mice increased hepcidin expression and lowered liver iron levels(16). This finding suggests that the liver is the central regulatory site for iron metabolism regulation. In a recent study, Garuti et al. reported that, when a liver with wild-type HFE was transplanted into a Hfe knock-out mouse, the hemochromatosis iron loading phenotype was reversed and hepcidin expression was normalized at the transcriptional level(17). From a clinical viewpoint, 
human case studies have not provided clear results. In some studies, a normal liver was transplanted into a patient with $\mathrm{HH}$, and in other studies, a $\mathrm{HH}$ liver was transplanted into normal patients (18-22). The results did not show the expected evolution of iron burden due to these liver transplantations. Moreover, very few cases of $\mathrm{HH}$ have been reported, and among those, assessments of the iron burden were often incomplete, and the evolution of hepcidin levels was not documented.

In the setting of liver transplantation, poor survival rates have been generally associated with iron overload, particularly in patients with $\mathrm{HH}$, compared to patients with liver diseases of alcoholic or viral origin. It was suggested that hemochromatosis increased the propensity for infections and associated cardiovascular diseases(23-27). However, those studies were limited by various biases; for example, earlier studies were performed before the availability of $\operatorname{HFE}(23,24)$ testing, and thus, associations with hemochromatosis were likely to reflect various conditions that caused iron overload. More recent studies have identified patients with confirmed HFE mutations, with a family history of $\mathrm{HH}$, or with a HLA A3B7 haplotype; in those studies, either the diagnosis was retrospective and included historical cases with a highly severe phenotype(26, 27), or the control populations were not representative of other liver diseases (27). Consequently, it remains a matter of debate whether survival after liver transplantation is affected by HFE C282Y homozygosity and iron overload.

Therefore, the present study aimed $(a)$ to evaluate the role of the liver in regulating iron metabolism, based on the long-term evolution of iron metabolism after liver transplantation in patients homozygous for HFE C282Y; and $(b)$ to analyze survival after transplantation in patients homozygous for HFE C282Y compared to patients that received transplants for other liver diseases, but underwent similar surgical procedures and medical management over the same time period. 


\section{PATIENTS AND METHODS}

\section{PATIENTS}

All patients that underwent a first, single organ, liver transplantation in our center from 01/01/1999 to $12 / 31 / 2008$ were eligible for our study. We collected data regarding underlying liver disease, indications for liver transplantation, and pre-transplantation liver function evaluations (Child-Pugh Score) from the national transplant registry database (Agence de la Biomédecine). The records of patients with hemochromatosis were reviewed. A local database of patients with HFE-related hemochromatosis was compared with the records of patients that underwent liver transplantations to identify patients that may have been omitted. Patients were included in the HFE hemochromatosis group only when HFE C282Y homozygosity was confirmed by genetic testing. In 2009, patients with HFE hemochromatosis were asked to participate in this study to reassess their iron metabolism, and they provided informed, written consent. This study was in accordance with the declaration of Helsinki. According to national policy no donor organs were obtained from executed prisoners or other institutionalized persons.

\section{FOLLOW UP DATA}

Patients were followed as outpatients at least once per year. The date and cause of death data were acquired prospectively from patient records or by directly contacting the general practitioners within the framework of the national transplant registry. Serum samples obtained before liver transplantation that were available in the serum bank were acquired for performing biochemical tests. The vital status of each patient was determined from the status recorded at the last follow-up visit to our center. Iron-related treatment data were retrospectively collected from the records, and reviewed with the patient at the time of the inclusion visit. Patients lost to follow-up or to graft loss were considered deceased. The end of follow-up was fixed as the $30^{\text {th }}$ of June 2012. 
IRON METABOLISM

Biochemical tests were performed on serum samples to assess iron metabolism (serum iron, serum transferrin, transferrin saturation, serum ferritin) and to measure $C$ reactive protein. Serum samples were obtained before liver transplantation and during the follow-up. Samples before liver transplantation were obtained from serum bank gathered in fasting patients during the evaluation before liver transplantation and stored at $-80^{\circ} \mathrm{C}$. Serum hepcidin levels were determined with an enzyme immunoassay (Peninsula Laboratories, Bachem, San Carlos USA) which was evaluated in a Round Robin 2 for Hepcidin assay and was shown to have satisfactory reliability (28). Serum hepcidin/ferritin ratios were calculated as follows: (serum hepcidin/serum ferritin) X100.

At the inclusion visit, the liver iron concentration (LIC) was determined with magnetic resonance imaging (MRI).(29) Spleen iron concentration was semi-quantitatively estimated with MRI and the same method used for the liver.

\section{STATISTICAL METHODS}

Results are reported as the median value \pm standard deviation. Quantitative variables were compared with the Wilcoxon signed rank test. Cumulative survival estimates and survival curves of patients with liver transplants were determined with the Kaplan Meyer method. Survival curves were compared between groups with the Log Rank test. Statistics were performed with SPSS 17.0. All tests were two-tailed, and the statistical significance level was set at $p<0.05$. 


\section{RESULTS}

\section{PATIENT CHARACTERISCS}

From 1999 to 2008, 736 patients underwent a first liver transplantation, 340 had alcoholic liver disease (65 with hepatocellular carcinoma [HCC]), 96 had viral hepatitis C (21 with HCC), 34 had acute liver failure, 20 had viral hepatitis B, 53 had congenital or auto-immune biliary diseases, 61 had other liver diseases (auto-immune hepatitis, vascular disease, enzymatic deficiencies, rare tumors), 114 had HCC without definite information for the underlying disease, and 18 had HFE-related hemochromatosis. The characteristics of the patients that received liver transplants to treat $C 282 Y$ HFE-related hemochromatosis are presented in Table 1 . The mean age at diagnosis of hemochromatosis was $48.7( \pm 7)$ years and the mean age at liver transplantation was $56( \pm 7)$ years; the mean follow-up time after liver transplantation was $68 \pm 45$ months. The main indication for liver transplantation was HCC without liver failure.

\section{EVOLUTION OF IRON BURDEN AND SERUM HEPCIDIN LEVELS}

We evaluated iron metabolism in 16 of the 18 patients with available biological samples collected before liver transplantation (at the time of liver transplantation evaluation). Eleven patients were fully iron depleted before liver transplantation, whereas five patients received the liver transplantation before total iron depletion was fully obtained with phlebotomy treatment. These patients received a diagnosis of hemochromatosis concomitant with the liver transplantation indication diagnosis. One patient did not undergo any phlebotomy before liver transplantation. Biochemical evaluations of iron metabolism after liver transplantation were available for 15 of the 18 patients at different time points during follow-up (Table 2). Only one patient required occasional bloodletting (less than 3 times a year) after liver transplantation.

The median follow-up time for the iron burden evaluation was $60 \pm 35$ months. The median serum transferrin saturation was $68 \pm 30 \%$ before, and $28 \pm 8.5 \%$ after liver transplantation $(p=0.021)$. Before liver transplantation, the median serum hepcidin level $(\mathrm{N}=4-30)$ and hepcidin/ferritin ratio $(\mathrm{N}=4-30)$ were $1.61 \pm 3.6 \mathrm{nmol} / \mathrm{L}$ and 0.35 \pm 3.6 , respectively. After liver transplantation, hepcidin levels significantly increased $(13.2 \pm 8.1 \mathrm{nmol} / \mathrm{L}$, 
$p=0.006)$ and hepcidin/ferritin ratios significantly increased (6.93 $\pm 8.75, p=0.015)$. All except one patient achieved normal hepcidin values. This patient had pulmonary fibrosis, which required continuous oxygen therapy. The patient eventually died of respiratory failure. His serum ferritin and transferrin saturation levels were normal.

The LIC, determined by MRI, was available for 11 patients (Table 2). Two patients had hepatic iron overload; of these, one patient $\left(n^{\circ}\right.$ ) had slightly elevated serum ferritin with normal transferrin saturation and mild LIC elevation. This patient was followed for recurrence of excessive alcohol consumption and had features of metabolic syndrome (diabetes, body mass index $=31$, waist circumference $=104 \mathrm{~cm}$, and high serum triglyceride levels). The other patient $\left(n^{\circ} 8\right)$ had high serum ferritin and LIC values and was followed for hereditary spherocytosis that was unmasked only after liver transplantation (hemoglobin level: 7-10 g/dl). This patient's post-liver transplantation history included transfusions, iron supplementation, and erythropoietin treatment, while she had no history of hematological condition during the 20 years of phlebotomy treatment for hemochromatosis before liver transplantation.

\section{SURVIVAL AND CAUSES OF DEATH}

Overall patient survival was $89 \%$ at one year, $70 \%$ at 5 years, and $55 \%$ at 10 years. Survival of patients with $\mathrm{HH}$ was $83 \%$ at one year and $67 \%$ at five years. The follow-up durations and causes of death for patients with $\mathrm{HH}$ are detailed in Table 1. Patients mainly died of sepsis or cancer; only one fatal vascular event occurred. KaplanMeier survival curves are shown in Figure 1. There were no statistical differences (Log Rank test: $p=0.40$ ) between survival of patients with $\mathrm{HH}$ and the control population (Figure $1 \mathrm{~A}$ ).

Among our entire population, we separated out all patients $(n=135)$ that received liver transplantations for HCC without liver failure (Child-Pugh score $\leq 6$ ), regardless of the underlying disease, and compared these to patients with $\mathrm{HH}$. The survival curves are shown in Figure 1B. The log rank test did not detect any statistical difference between survival of patients with HCC and those with $\mathrm{HH}(\mathrm{p}=0.56)$.

Finally, we compared survival according to the underlying disease, regardless of the indication for liver transplantation. The patients were allocated to groups with alcoholic liver disease, hepatitis $\mathrm{C}$, and acute liver 
failure. We compared survival of these groups to that of the $\mathrm{HH}$ group (Figure 1C). The log rank test indicated that patients with hepatitis $\mathrm{C}$ had significantly lower survival rates than those with alcoholic liver diseases $(p=0.001)$ and those with acute liver failure $(p=0.024)$. All other comparisons showed no statistically significant differences. 
This study was the first to report long-term follow-up data on serum hepcidin and iron metabolism profiles after liver transplantation in a well-defined group of patients homozygous for HFE C282Y. In addition, it is the first to definitely demonstrate the paramount role of liver in human $\mathrm{HH}$. Our results showed, as expected, that patients with $\mathrm{HH}$ had low serum hepcidin levels, and that serum hepcidin levels were normalized after liver transplantation. Moreover, we found that, after a median follow-up of 5 years without iron depletion treatment, in patients without confounding factors, normal serum hepcidin levels were associated with normal biological iron metabolism and normal liver iron content, based on MRI. The patient and graft survival rates after liver transplantation were not significantly different between patients with $\mathrm{HH}$ and the overall population of patients that received liver transplantations.

These results shed light on the evolution of iron burden in patients with $\mathrm{HH}$. Although our cohort of patients was relatively small, we used rigorous selection criteria that excluded other causes of iron overload. Moreover, the iron burden assessment was based on biochemical and imaging data that were available over a long followup period.

Several case report studies $(18-22,30,31)$ have previously attempted to elucidate the role of the liver in $\mathrm{HH}$. However, the results showed discrepancies, and they precluded definite conclusions, due to the small numbers of patients, the lack of genetic testing, the short-term follow-ups, and the lack of hepcidin assessments. Kowdley et al. (27) studied LIC after liver transplantation of patient with HH. Their results indicated that iron overload did not recur in patients with $\mathrm{HH}$, based on measurements of serum transferrin saturation and serum ferritin levels. However, they lacked LIC assessments for half of the surviving patients. Moreover, that study was performed before the discovery of hepcidin's role in iron metabolism (7); thus, no data was available on hepcidin secretion.

In the present study, after liver transplantation, we found no increases in serum transferrin saturation, considered the earliest biochemical event in $\mathrm{HH}$. In addition, we found no hepatic iron overload in the entire study group. Importantly, in our series, only one patient received occasional phlebotomy treatment after transplantation, which could have hampered the recurrence of iron overload. We found two patients with 
modified iron parameters, but they both exhibited comorbidities that influenced iron metabolism. This finding underlined the importance of a careful search for potential confounding cofactors.

One of the major difficulties in describing the outcome of $\mathrm{HH}$ after liver transplantation has been the lack of definite markers for $\mathrm{HH}$ and its variable expression (32). However, we were able to measure serum hepcidin, which exerts a primary regulatory role in iron metabolism and in hemochromatosis expression (33, 34). This provided a more precise, relevant evaluation of liver transplantation outcome. In mice, Garuti et al. (17), found that transplantation of HFE wild type livers in HFE knock-out mice resulted in normal hepatic hepcidin expression at the mRNA level and a trend toward decreased iron burden. Moreover, transplantation of $H F E$ knock-out livers in HFE wild type mice resulted in low hepatic hepcidin expression and the occurrence of iron overload. Here, we used this hepcidin approach for evaluating human liver transplantations. We established for the first time that serum hepcidin levels, which were abnormally low before liver transplantation, were fully normalized after liver transplantation.

Our finding that serum hepcidin levels were low before liver transplantation was consistent with previous studies in patients with $\mathrm{HH}$. Moreover, we confirmed that the hepcidin/ ferritin ratio was preferable to the serum hepcidin evaluation. Among five patients $\left(n^{\circ} 3,4,10,15\right.$ and 18$)$ with normal hepcidin values before liver transplantation, three $\left(n^{\circ} 3,4\right.$ and 15$)$ had very high ferritin values; thus, the hepcidin/ferritin ratio was low, due to inadequate hepcidin synthesis, and this confirmed the hepcidin-deficient phenotype. Two patients had normal hepcidin levels and hepcidin/ferritin ratios $\left(n^{\circ} 10,18\right)$; both were diagnosed with HCC. We speculate that inflammation, related either to the cancer disease, or to the effect of cancer treatment applied during the time the patient spent on the waiting list, or abnormal hepcidin secretion by the tumor, contributed to the normal hepcidin levels for these patients. Of note, two patients ( ${ }^{\circ} 1$ and 5 ) had normal ratios, with very low hepcidin and serum ferritin levels. This could indicate that the hepcidin/ferritin ratio may be inadequate in cases with low serum ferritin levels. The same explanation may apply to patients 1 and 18 who, after transplantation, presented with abnormally low hepcidin / ferritin ratio. Cirrhosis itself has been associated with reduced hepatic expression, however most of our patients were free of liver failure therefore it is unlikely to have modified our serum hepcidin value. Since hepcidin levels have been shown to decrease during the induction phase of phlebotomy treatment (9), we cannot exclude that this factor contributed to the pretransplantation decreased hepdicin values. However, the data obtained with the hepcidin/ferritin ratios 
indicated that hepcidin remained relatively low when compared to the degree of iron stores, accordingly to the observations previously reported in patients exhibiting HFE hemochromatosis, and at a similar level to that of the untreated patients.

After liver transplantation, serum hepcidin was normalized, and iron parameters remained normal for 5 years. This confirmed that the liver was the main producer of hepcidin in humans, and that normalization of hepcidin levels in the serum was associated with reversion of abnormal iron metabolism. Two patients with very high ferritin levels before transplant normalized their ferritin values after transplantation. It is possible that taking out most of the iron burden by removing the diseased liver, and restoring normal iron regulation with the new liver, may have led to this evolution. Altogether, these data supported the view that hepcidin is a major actor in systemic iron regulation, and it agreed with previous data obtained in mice $(17,34)$ ENREF 33.

It is likely that hepatic transplantation might also cure other genetic forms of hemochromatosis, unrelated to $\mathrm{HH}$; for example, iron overload due to mutations in HJV, HAMP, or TFR2 genes. Indeed, like HFE, both HJV and TFR2 genes are involved in the transduction of signals related to iron sensing. Furthermore, like HFE, these two genes are expressed at the level of the hepatocyte membrane. This observation takes on particular importance when we consider that that these three mutated genes may be responsible for severe forms of juvenile hemochromatosis. Although the HFE gene is expressed in a large number of tissues (2), our clinical data support the view that HFE expression in non-liver cells is unlikely to play a major role in iron metabolism during genetic hemochromatosis.

This study also addressed the important, debated issue of patient and graft survival after liver transplantation in patients with $\mathrm{HH}$. Our results showed that survival rates were not significantly different in patients with $\mathrm{HH}$ and the overall population of patients that received liver transplants. However, this result contrasted with previous reports (23-27). Indeed, liver transplantation in patients with $\mathrm{HH}$ has been associated with lower survival, due to more frequent infections and cardiovascular diseases (27). However, some of those studies were conducted before definitive criteria were available for $\mathrm{HH}$ diagnosis. For example, Kowdley et al. (27) diagnosed $\mathrm{HH}$ in patients prior to liver transplantation, but only $43 \%$ of patients underwent a genetic test confirmation. It is known that iron overload can occur in various liver diseases, and it can increase with the severity of the disease (35-37). In a study by Brandhagen et al.,(38) only $10 \%$ of transplanted patients with iron 
overload were homozygous for HFE C282Y. Moreover, most previous studies lacked an evaluation of liver disease severity with the Child-Pugh score. Thus, the lack of a definitive diagnosis, combined with the possible selection of severe patients at inclusion could have induced a selection bias, which influenced the findings that HH was associated with increased complications and mortality.

The present study included patients that were prospectively diagnosed and genetically confirmed for $\mathrm{HH}$. These patients showed survival rates similar to those of the overall population. When we assessed survival according to the underlying liver disease, we did not find differences between patients with $\mathrm{HH}$ and those with other liver diseases. Most of our patients were iron depleted before liver transplantation; only six had presented biological signs of iron overload at the time of liver transplantation. Thus, we did not have sufficient statistical power to assess survival between iron depleted and non-iron depleted patients. However, it is likely that the previously described low survival rates of patients with $\mathrm{HH}$ were related to iron overload, regardless of the underlying disease, rather than specifically related to the genetic defect. This hypothesis is consistent with the recent study by Yu et al. (39) which showed that post-liver transplantation survival in patients with hemochromatosis was higher in studies conducted more recently compared to survival reported in older studies. However, as acknowledged by the authors, that study lacked definitive genetic diagnoses of patients with $\mathrm{HH}$ and did not consider the potential association between HCC and hemochromatosis.

It is noteworthy that, in our population, HCC was the main indication for liver transplantation. In addition, only one patient had liver failure associated with excessive alcohol intake. This observation was fully consistent with the natural history of liver cirrhosis in $\mathrm{HH}$, where liver failure is rarely seen in the absence of hepato-toxic cofactors (the case in nearly all our patients). Therefore, this confirmed that the major liver complication in $\mathrm{HH}$ was HCC, consistent with our experience and also with a study by Fracanzani et al. (40) A study by Crawford et al. (26) showed that, in patients with genetic hemochromatosis that received liver transplants, mortality was mainly related to HCC recurrence. However, some patients exhibited a tumor that was not within the Milan criteria, because the study was performed before the establishment of HCC guidelines. In contrast, we found that our patients with $\mathrm{HH}$ (mainly diagnosed with $\mathrm{HCC}$ classified as Child-Pugh A cirrhosis) had survival rates similar to our control population of patients that received liver transplants for treating HCC (also diagnosed with Child-Pugh A cirrhosis). Thus, among patients with and without $\mathrm{HH}$, defined with the same currently 
accepted criteria, the patients with $\mathrm{HH}$ did not exhibit increased risk of HCC recurrence after liver transplantation.

In conclusion, our study in humans demonstrated that liver transplantation cured the iron overload phenotype and the biological defects in $\mathrm{HH}$ by normalizing hepcidin synthesis. These data further supported the notion that the liver plays a primary role in iron metabolism. Moreover, our results showed that survival of patients with $\mathrm{HH}$ after liver transplantation was similar to that of the overall population of patients that received liver transplants. 


\section{REFERENCES}

1. Simon M, Bourel M, Genetet B, Fauchet R. Idiopathic hemochromatosis. Demonstration of recessive transmission and early detection by family HLA typing. N Engl J Med 1977;297:1017-1021.

2. Feder JN, Gnirke A, Thomas W, Tsuchihashi Z, Ruddy DA, Basava A, Dormishian F, et al. A novel MHC class I-like gene is mutated in patients with hereditary haemochromatosis. Nat Genet 1996;13:399-408.

3. Brissot $P$, Bardou-Jacquet $E$, Jouanolle $A M$, Loreal O. Iron disorders of genetic origin: a changing world. Trends Mol Med 2011;17:707-713.

4. Parkkila S, Waheed A, Britton RS, Feder JN, Tsuchihashi Z, Schatzman RC, Bacon BR, et al. Immunohistochemistry of HLA-H, the protein defective in patients with hereditary hemochromatosis, reveals unique pattern of expression in gastrointestinal tract. Proc Natl Acad Sci U S A 1997;94:2534-2539.

5. Parkkila S, Niemela O, Britton RS, Fleming RE, Waheed A, Bacon BR, Sly WS. Molecular aspects of iron absorption and HFE expression. Gastroenterology 2001;121:1489-1496.

6. Park $\mathrm{CH}$, Valore EV, Waring AJ, Ganz T. Hepcidin, a urinary antimicrobial peptide synthesized in the liver. J Biol Chem 2001;276:7806-7810.

7. Pigeon C, Ilyin G, Courselaud B, Leroyer $P$, Turlin B, Brissot $P$, Loreal O. A new mouse liver-specific gene, encoding a protein homologous to human antimicrobial peptide hepcidin, is overexpressed during iron overload. J Biol Chem 2001;276:7811-7819.

8. Nemeth E, Tuttle MS, Powelson J, Vaughn MB, Donovan A, Ward DM, Ganz T, et al. Hepcidin regulates cellular iron efflux by binding to ferroportin and inducing its internalization. Science 2004;306:2090-2093.

9. van Dijk BA, Laarakkers CM, Klaver SM, Jacobs EM, van Tits LJ, Janssen MC, Swinkels DW. Serum hepcidin levels are innately low in HFE-related haemochromatosis but differ between C282Y-homozygotes with elevated and normal ferritin levels. Br J Haematol 2008;142:979-985.

10. Feder JN, Penny DM, Irrinki A, Lee VK, Lebron JA, Watson N, Tsuchihashi Z, et al. The hemochromatosis gene product complexes with the transferrin receptor and lowers its affinity for ligand binding. Proc Natl Acad Sci U S A 1998;95:1472-1477.

11. D'Alessio F, Hentze MW, Muckenthaler MU. The hemochromatosis proteins HFE, TfR2, and HJV form a membrane-associated protein complex for hepcidin regulation. J Hepatol 2012.

12. Goswami T, Andrews NC. Hereditary hemochromatosis protein, HFE, interaction with transferrin receptor 2 suggests a molecular mechanism for mammalian iron sensing. J Biol Chem 2006;281:28494-28498.

13. Zhou XY, Tomatsu S, Fleming RE, Parkkila S, Waheed A, Jiang J, Fei Y, et al. HFE gene knockout produces mouse model of hereditary hemochromatosis. Proc Natl Acad Sci U S A 1998;95:2492-2497.

14. Ahmad KA, Ahmann JR, Migas MC, Waheed A, Britton RS, Bacon BR, Sly WS, et al. Decreased liver hepcidin expression in the Hfe knockout mouse. Blood Cells Mol Dis 2002;29:361-366.

15. Vujic Spasic M, Kiss J, Herrmann T, Galy B, Martinache S, Stolte J, Grone HJ, et al. Hfe acts in hepatocytes to prevent hemochromatosis. Cell Metab 2008;7:173-178.

16. Gao J, Chen J, De Domenico I, Koeller DM, Harding CO, Fleming RE, Koeberl DD, et al. Hepatocytetargeted HFE and TFR2 control hepcidin expression in mice. Blood 2010;115:3374-3381. 
17. Garuti C, Tian Y, Montosi G, Sabelli M, Corradini E, Graf R, Ventura P, et al. Hepcidin expression does not rescue the iron-poor phenotype of Kupffer cells in Hfe-null mice after liver transplantation. Gastroenterology 2010;139:315-322 e311.

18. Adams PC, McAlister V, Chakrabarti S, Levstik M, Marotta P. Is serum hepcidin causative in hemochromatosis? Novel analysis from a liver transplant with hemochromatosis. Can J Gastroenterol 2008;22:851-853.

19. Dwyer JP, Sarwar S, Egan B, Nolan N, Hegarty J. Hepatic iron overload following liver transplantation of a C282y homozygous allograft: a case report and literature review. Liver Int 2011;31:1589-1592.

20. Ismail MK, Martinez-Hernandez A, Schichman S, Chaudhry S, Waters B. Transplantation of a liver with the $\mathrm{C} 282 \mathrm{Y}$ mutation into a recipient heterozygous for $\mathrm{H63D}$ results in iron overload. Am J Med Sci 2009;337:138-142.

21. Adams PC, Jeffrey G, Alanen K, Chakrabarti S, Preshaw R, Howson W, Grant D. Transplantation of haemochromatosis liver and intestine into a normal recipient. Gut 1999;45:783.

22. Adams PC, Ghent CN, Grant DR, Frei JV, Wall WJ. Transplantation of a donor liver with haemochromatosis: evidence against an inherited intrahepatic defect. Gut 1991;32:1082-1083.

23. Kilpe VE, Krakauer H, Wren RE. An analysis of liver transplant experience from 37 transplant centers as reported to Medicare. Transplantation 1993;56:554-561.

24. Kowdley KV, Hassanein T, Kaur S, Farrell FJ, Van Thiel DH, Keeffe EB, Sorrell MF, et al. Primary liver cancer and survival in patients undergoing liver transplantation for hemochromatosis. Liver Transpl Surg 1995;1:237-241.

25. Tung BY, Farrell FJ, McCashland TM, Gish RG, Bacon BR, Keeffe EB, Kowdley KV. Long-term follow-up after liver transplantation in patients with hepatic iron overload. Liver Transpl Surg 1999;5:369-374.

26. Crawford DH, Fletcher LM, Hubscher SG, Stuart KA, Gane E, Angus PW, Jeffrey GP, et al. Patient and graft survival after liver transplantation for hereditary hemochromatosis: Implications for pathogenesis. Hepatology 2004;39:1655-1662.

27. Kowdley KV, Brandhagen DJ, Gish RG, Bass NM, Weinstein J, Schilsky ML, Fontana RJ, et al. Survival after liver transplantation in patients with hepatic iron overload: the national hemochromatosis transplant registry. Gastroenterology 2005;129:494-503.

28. Kroot JJ, van Herwaarden AE, Tjalsma H, Jansen RT, Hendriks JC, Swinkels DW. Second round robin for plasma hepcidin methods: first steps toward harmonization. Am J Hematol;87:977-983.

29. Gandon Y, Olivie D, Guyader D, Aube C, Oberti F, Sebille V, Deugnier Y. Non-invasive assessment of hepatic iron stores by MRI. Lancet 2004;363:357-362.

30. Dabkowski PL, Angus PW, Smallwood RA, Ireton J, Jones RM. Site of principal metabolic defect in idiopathic haemochromatosis: insights from transplantation of an affected organ. BMJ 1993;306:1726.

31. Koskinas J, Portmann B, Lombard M, Smith T, Williams R. Persistent iron overload 4 years after inadvertent transplantation of a haemochromatotic liver in a patient with primary biliary cirrhosis. J Hepatol 1992;16:351-354.

32. Allen KJ, Gurrin LC, Constantine CC, Osborne NJ, Delatycki MB, Nicoll AJ, McLaren CE, et al. Ironoverload-related disease in HFE hereditary hemochromatosis. N Engl J Med 2008;358:221-230.

33. Muckenthaler M, Roy CN, Custodio AO, Minana B, deGraaf J, Montross LK, Andrews NC, et al. Regulatory defects in liver and intestine implicate abnormal hepcidin and Cybrd1 expression in mouse hemochromatosis. Nat Genet 2003;34:102-107. 
34. Nicolas G, Viatte L, Lou DQ, Bennoun M, Beaumont C, Kahn A, Andrews NC, et al. Constitutive hepcidin expression prevents iron overload in a mouse model of hemochromatosis. Nat Genet 2003;34:97-101.

35. O'Glasser AY, Scott DL, Corless CL, Zaman A, Sasaki A, Gopal DV, Rayhill SC, et al. Hepatic and cardiac iron overload among patients with end-stage liver disease referred for liver transplantation. Clin Transplant 2010;24:643-651.

36. Ludwig J, Hashimoto E, Porayko MK, Moyer TP, Baldus WP. Hemosiderosis in cirrhosis: a study of 447 native livers. Gastroenterology 1997;112:882-888.

37. Deugnier Y, Turlin B, le Quilleuc D, Moirand R, Loreal O, Messner M, Meunier B, et al. A reappraisal of hepatic siderosis in patients with end-stage cirrhosis: practical implications for the diagnosis of hemochromatosis. Am J Surg Pathol 1997;21:669-675.

38. Brandhagen DJ, Alvarez W, Therneau TM, Kruckeberg KE, Thibodeau SN, Ludwig J, Porayko MK. Iron overload in cirrhosis-HFE genotypes and outcome after liver transplantation. Hepatology 2000;31:456-460.

39. Yu L, Ioannou GN. Survival of liver transplant recipients with hemochromatosis in the United States. Gastroenterology 2007;133:489-495.

40. Fracanzani AL, Piperno A, Valenti L, Fraquelli M, Coletti S, Maraschi A, Consonni D, et al. Hemochromatosis in Italy in the last 30 years: role of genetic and acquired factors. Hepatology 2010;51:501510. 
Figure 1: Kaplan Meier survival curves of patients that received liver transplants, grouped according to the underlying liver disease. Panel A: HH (long dot line): HFE related hemochromatosis, Non HH (dotted line)_: liver disease not related to HH. Panel B: HH (dotted line): Patient with HH and Hepatocellular carcinoma. HCC (plain line): patient with Hepatocellular carcinoma and liver disease other than HH. Panel C: ALF: Acute Liver Failure. HH: HFE related hemochromatosis. Alcohol: alcoholic liver disease. HCV: Hepatitis C virus related liver disease. 


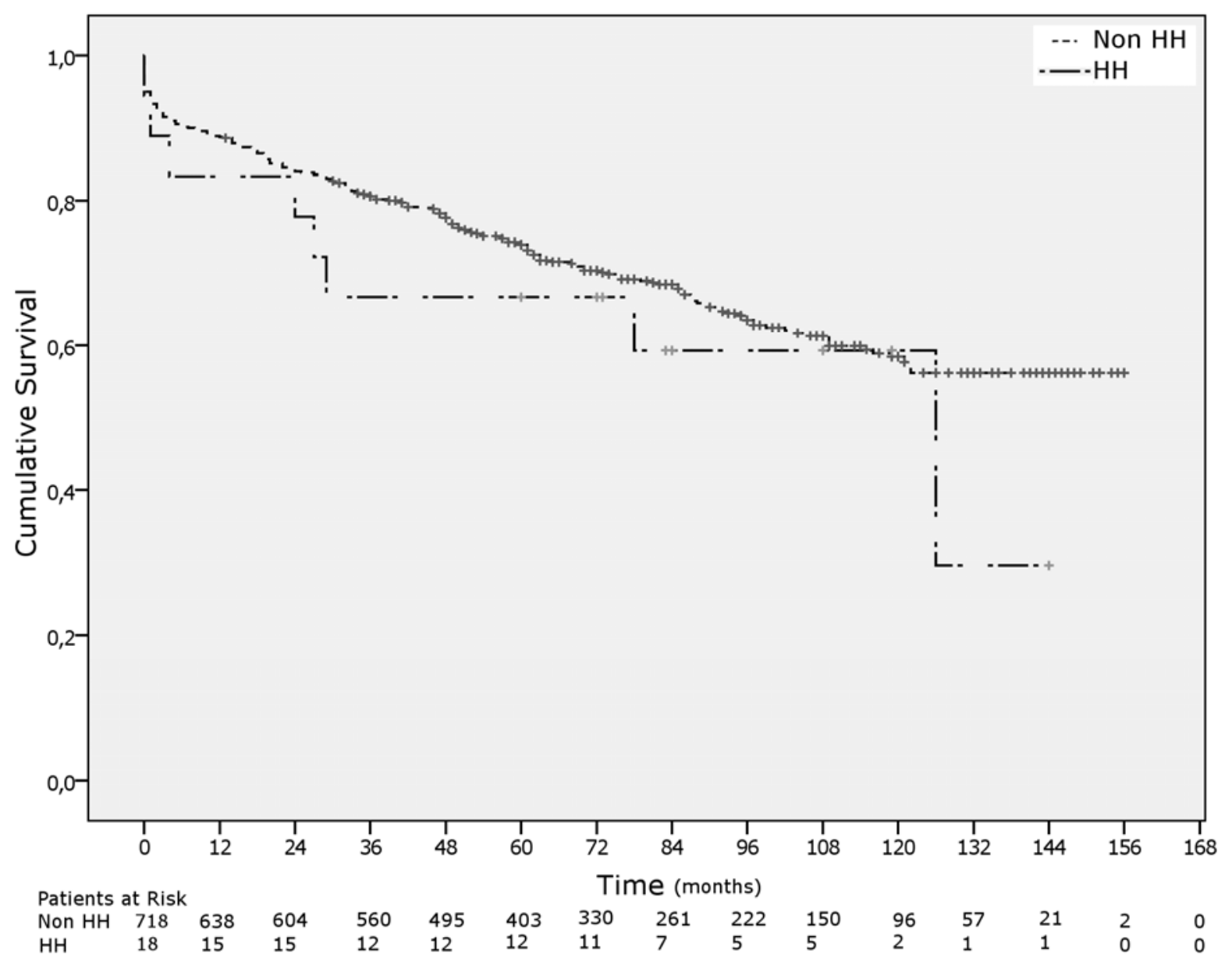




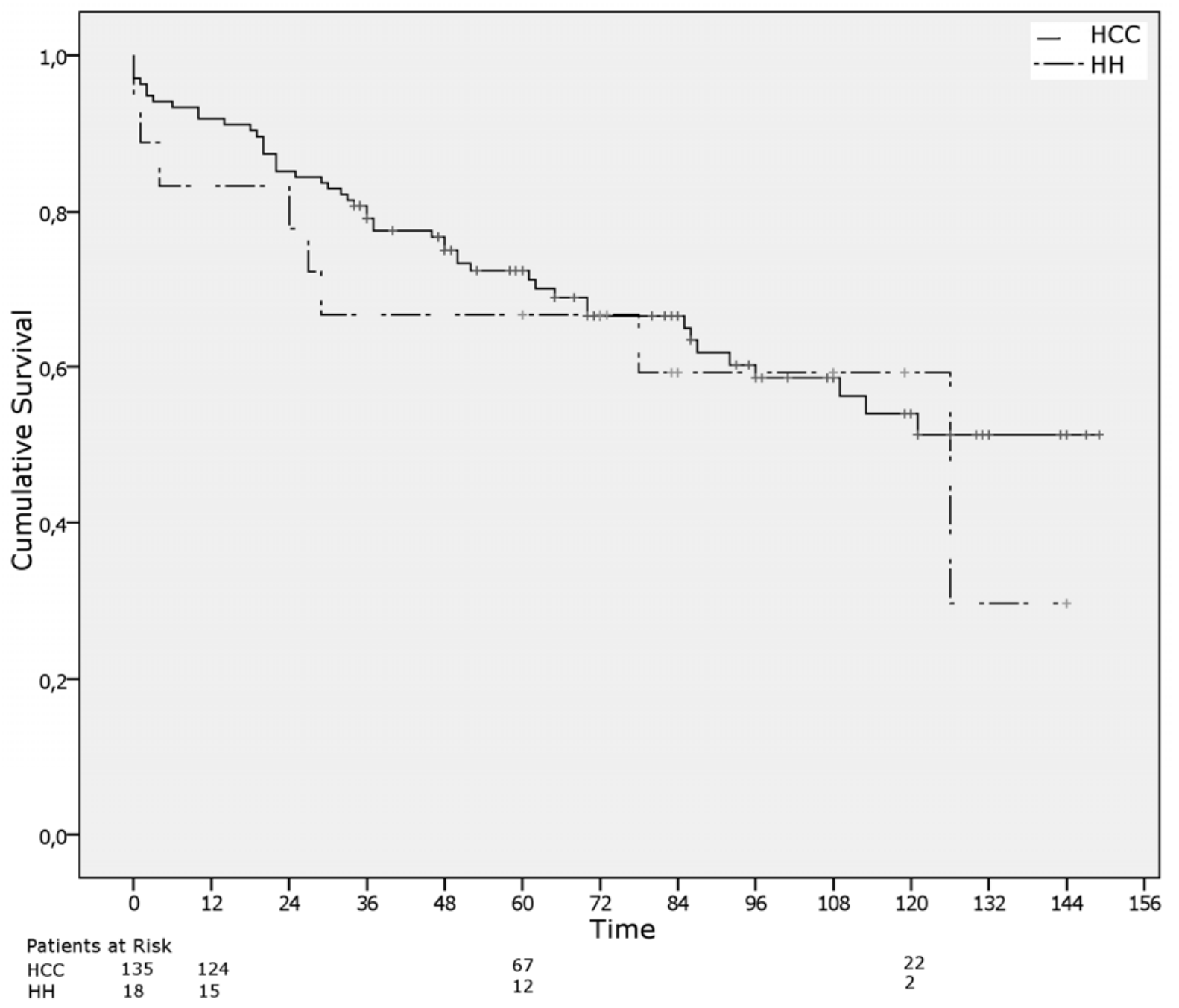




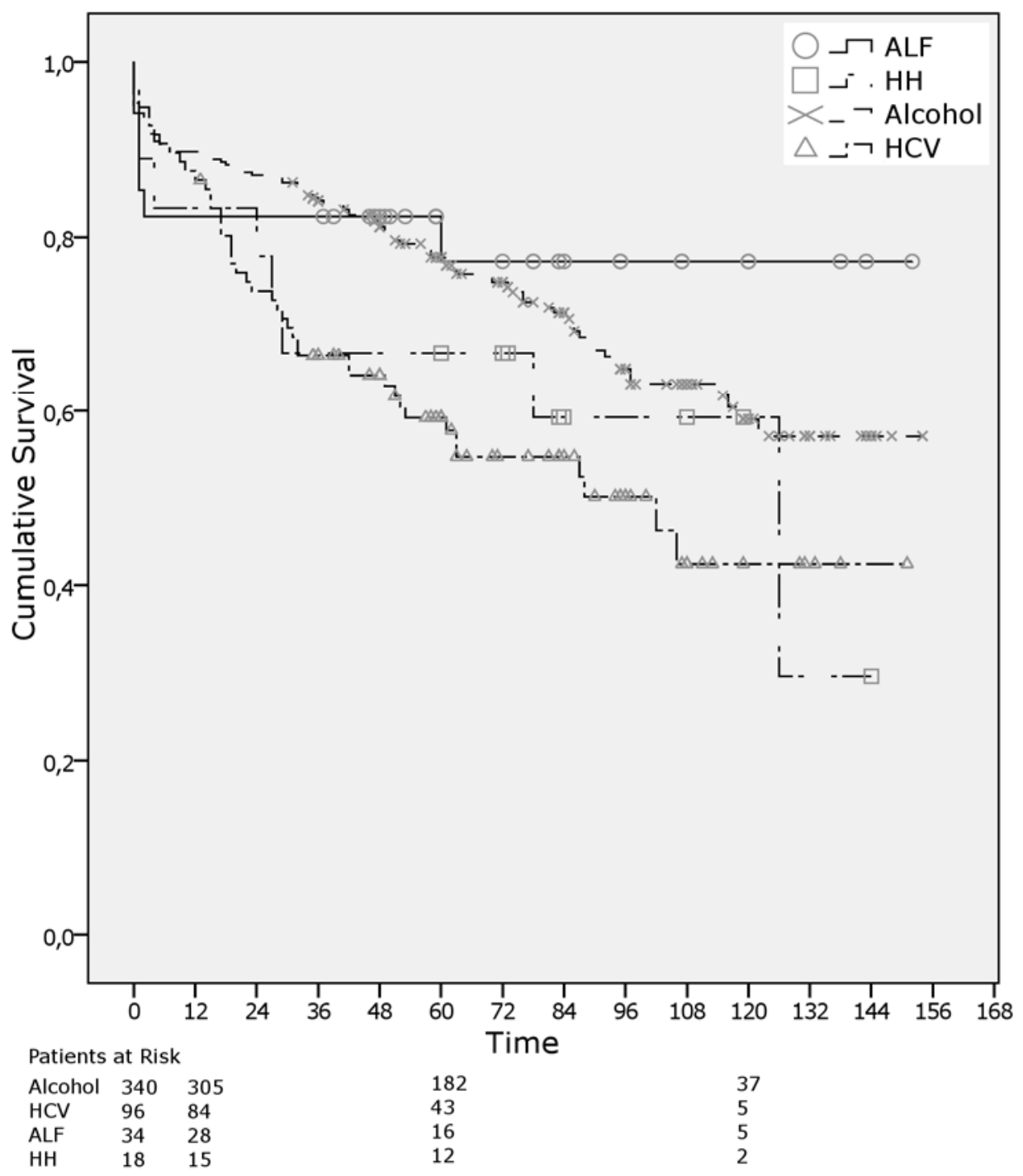


Table 1: Clinical characteristics of patients that received liver transplants to treat HFE hemochromatosis. LT: liver transplantation; Child-Pugh score (scale 5-15) used for assessing prognosis of chronic liver disease; HCC: Hepatocellular carcinoma.

\begin{tabular}{|c|c|c|c|c|c|c|}
\hline & $\begin{array}{l}\text { Age at diagnosis } \\
\text { (years) }\end{array}$ & $\begin{array}{l}\text { Age at LT } \\
\text { (years) }\end{array}$ & $\begin{array}{l}\text { Associated } \\
\text { Liver disease }\end{array}$ & Indication for LT & $\begin{array}{l}\text { Child-Pugh } \\
\text { at LT }\end{array}$ & $\begin{array}{l}\text { Survival (months) / } \\
\text { cause of death }\end{array}$ \\
\hline Patient 1 & 33 & 36 & & $\begin{array}{l}\text { Biliary } \\
\text { Hamartoma }\end{array}$ & A5 & 60 / Alive \\
\hline Patient 2 & 54 & 55 & & $\mathrm{HCC}$ & A5 & 72 / Alive \\
\hline Patient 3 & 46 & 55 & & $\mathrm{HCC}$ & A5 & 73 / Alive \\
\hline Patient 4 & 47 & 54 & & $\mathrm{HCC}$ & A5 & 83 / Alive \\
\hline Patient 5 & 43 & 54 & & $\mathrm{HCC}$ & A5 & 84 / Alive \\
\hline Patient 6 & 39 & 60 & & $\mathrm{HCC}$ & B7 & 84 / Alive \\
\hline Patient 7 & 49 & 60 & & $\mathrm{HCC}$ & A5 & 108 / Alive \\
\hline Patient 8 & 45 & 65 & & $\mathrm{HCC}$ & A5 & 119 / Alive \\
\hline Patient 9 & 53 & 53 & Alcohol & $\mathrm{HCC}$ & A5 & 119 / Alive \\
\hline Patient 10 & 43 & 56 & Alcohol & $\mathrm{HCC}$ & A5 & 144 / Alive \\
\hline Patient 11 & 48 & 59 & & $\mathrm{HCC}$ & A5 & $\begin{array}{l}0 \text { / Hepatic artery } \\
\text { thrombosis, liver } \\
\text { abscess }\end{array}$ \\
\hline Patient 12 & 59 & 61 & & Liver failure & C13 & 1 / Sepsis (lung) \\
\hline Patient 13 & 62 & 63 & Alcohol & $\mathrm{HCC}$ & A5 & 4 / Sepsis (lung) \\
\hline Patient 14 & 51 & 60 & & $\mathrm{HCC}$ & A5 & $\begin{array}{l}24 \text { / HCC } \\
\text { recurrence }\end{array}$ \\
\hline Patient 15 & 53 & 54 & Alcohol & $\mathrm{HCC}$ & A5 & 27 / Lung cancer \\
\hline Patient 16 & 44 & 56 & Alcohol & $\mathrm{HCC}$ & A5 & 29 / Stroke \\
\hline Patient 17 & 56 & 66 & & $\mathrm{HCC}$ & A5 & 78 / Lung cancer \\
\hline Patient 18 & 52 & 55 & & $\mathrm{HCC}$ & A5 & 126 / Acute \\
\hline
\end{tabular}


respiratory failure

/ Pulmonary

fibrosis

Table 2: Clinical and biological data before and after liver transplantation (LT) in patients with HFE-related hemochromatosis $(\mathrm{HH})$

HH complication: HFE hemochromatosis-related complications. Phlebotomy: ongoing phlebotomy treatment. RBC LT: amount of red blood cell transfusions during LT surgery. MRI: magnetic resonance imaging. 


\begin{tabular}{|c|c|c|c|c|c|c|c|c|c|c|c|c|c|c|c|c|c|}
\hline \multirow[b]{3}{*}{ Patients } & \multicolumn{6}{|c|}{ Before Liver Transplantation } & \multirow{3}{*}{$\begin{array}{l}\text { LT } \\
\text { RBC } \\
\text { LT }\end{array}$} & \multicolumn{10}{|c|}{ After Liver Transplantation } \\
\hline & \multirow[b]{2}{*}{$\begin{array}{l}\text { HH } \\
\text { complication }\end{array}$} & \multirow[b]{2}{*}{$\begin{array}{l}\text { Phlebot } \\
\text { omy }\end{array}$} & \multirow{2}{*}{$\begin{array}{l}\text { Serum } \\
\text { Ferritin } \\
(\mu \mathrm{g} / \mathrm{L})\end{array}$} & \multirow{2}{*}{$\begin{array}{l}\text { Transferrin } \\
\text { saturation } \\
\text { (\%) }\end{array}$} & \multirow{2}{*}{$\begin{array}{l}\text { Serum } \\
\text { Hepcidin } \\
\text { (nmol/L) }\end{array}$} & \multirow{2}{*}{$\begin{array}{l}\text { Hepcidin } \\
\text { / ferritin } \\
\text { ratio }\end{array}$} & & \multirow[b]{2}{*}{$\begin{array}{l}\text { Phlebot } \\
\text { omy }\end{array}$} & \multirow{2}{*}{$\begin{array}{l}\text { Time to Re } \\
\text { evaluation } \\
\text { (month) }\end{array}$} & \multirow{2}{*}{$\begin{array}{l}\text { Serum } \\
\text { ferritin } \\
(\mu \mathrm{g} / \mathrm{L})\end{array}$} & \multirow{2}{*}{$\begin{array}{l}\text { Serum } \\
\text { Iron } \\
(\mu \mathrm{mol} / \mathrm{L} \\
)\end{array}$} & \multirow{2}{*}{$\begin{array}{l}\text { Transferrin } \\
\text { saturation } \\
\text { (\%) }\end{array}$} & \multirow{2}{*}{$\begin{array}{l}\text { Serum } \\
\text { hepcidin } \\
\text { (nmol/l) }\end{array}$} & \multirow[b]{2}{*}{$\begin{array}{l}\text { Hepcidin / } \\
\text { ferritin ratio }\end{array}$} & \multicolumn{2}{|c|}{ MRI } & \multirow[b]{2}{*}{ Co morbidities } \\
\hline & & & & & & & & & & & & & & & $\begin{array}{l}\text { Liver Iron } \\
\text { content }\end{array}$ & $\begin{array}{l}\text { Spleen iron } \\
\text { content }\end{array}$ & \\
\hline 1 & Fatigue & Yes & 8.6 & 10.5 & 0.9 & 10.46 & 0 & No & 35 & 10.7 & 14 & 18.7 & 3.94 & 36.8 & $\begin{array}{c}<40 \\
\mu \mathrm{mol} / \mathrm{g}\end{array}$ & Normal & Dyslipidemia \\
\hline 2 & No & Yes & 1178 & 87.4 & 0.36 & 0.03 & 4 & $\begin{array}{l}\text { Yes /4- } \\
5 \\
\text { month } \\
\mathrm{s}\end{array}$ & 47 & 129.2 & 14.3 & 34.3 & 8.96 & 6.9 & $\begin{array}{c}<40 \\
\mu \mathrm{mol} / \mathrm{g}\end{array}$ & Normal & No \\
\hline 3 & $\begin{array}{l}\text { Arthropathy, } \\
\text { Diabetes }\end{array}$ & Yes & 148 & 85,0 & 5,38 & 3,63 & 0 & No & \multicolumn{9}{|c|}{ Patient refused iron metabolism study } \\
\hline 4 & No & No & 3364 & 89.7 & 8.96 & 0.26 & 9 & No & 58 & 201.3 & 17.5 & 34.0 & 9.68 & 4.8 & $\begin{array}{c}<40 \\
\mu \mathrm{mol} / \mathrm{g}\end{array}$ & Normal & Diabetes \\
\hline 5 & $\begin{array}{l}\text { Arthropathy, } \\
\text { Diabetes }\end{array}$ & Yes & 31.5 & 19.0 & 2.33 & 7.39 & 0 & No & 60 & 228.1 & 22.2 & 37.9 & 26.17 & 11.4 & $\begin{array}{c}<40 \\
\mu \mathrm{mol} / \mathrm{g}\end{array}$ & Normal & $\begin{array}{l}\text { Diabetes, } \\
\text { Dyslipidemia }\end{array}$ \\
\hline 6 & Diabetes & Yes & 21.9 & 16.6 & 0.18 & 0.82 & 12 & No & 62 & 175.3 & 16.6 & 27.7 & 11.12 & 6.3 & $\begin{array}{c}<40 \\
\mu \mathrm{mol} / \mathrm{g}\end{array}$ & Normal & $\begin{array}{l}\text { Hypertension, } \\
\text { Diabetes }\end{array}$ \\
\hline 7 & Arthropathy & Yes & 49.1 & 26.9 & 0.18 & 0.36 & 4 & No & 86 & 163.5 & 13.9 & 27.1 & 14.34 & 8.7 & $\begin{array}{c}<40 \\
\mu \mathrm{mol} / \mathrm{g}\end{array}$ & Normal & No \\
\hline 8 & None & Yes & 69.1 & 75.2 & 0.18 & 0.26 & 8 & No & 89 & 588.7 & 9.85 & 26.4 & 23.84 & 4.0 & $\begin{array}{c}180 \\
\mu \mathrm{mol} / \mathrm{g}\end{array}$ & $\begin{array}{l}\text { Iron } \\
\text { overload } \\
+++\end{array}$ & 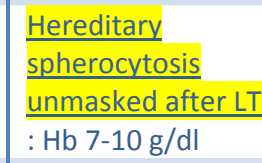 \\
\hline 9 & Diabetes & Yes & 1129 & 79.7 & 0.72 & 0.06 & 3 & No & 92 & 380 & 16 & 29.0 & 20.8 & 5.4 & $\begin{array}{c}70 \\
\mu \mathrm{mol} / \mathrm{g}\end{array}$ & $\begin{array}{l}\text { Slight } \\
\text { iron } \\
\text { overload }\end{array}$ & $\begin{array}{l}\text { Hypertension, } \\
\text { excessive alcohol } \\
\text { consumption }\end{array}$ \\
\hline 10 & Diabetes & Yes & 64.3 & 71.4 & 5.0 & 7.80 & 3 & No & 109 & 280 & 21.3 & 45.8 & 21.33 & 7.6 & $\begin{array}{c}<40 \\
\mu \mathrm{mol} / \mathrm{g}\end{array}$ & Normal & Hypertension \\
\hline 11 & Diabetes & Yes & \multicolumn{4}{|c|}{ No sample available } & 4 & No & \multicolumn{9}{|c|}{ Patient died before re-evaluation } \\
\hline 12 & No & Yes & 564,8 & 89,4 & 0,7 & 0,12 & 17 & No & \multicolumn{9}{|c|}{ Patient died before re-evaluation } \\
\hline 13 & No & Yes & 3908 & 89,6 & 3,97 & 0,10 & 4 & No & \multicolumn{9}{|c|}{ Patient died before re-evaluation } \\
\hline 14 & No & Yes & 181,6 & 84,0 & 3,54 & 1,95 & 7 & No & \multicolumn{9}{|c|}{ Patient died before re-evaluation } \\
\hline 15 & Fatigue & Yes & 3507 & 88,6 & 12,2 & 0,34 & 0 & No & 6 & 150 & 15.43 & 32.1 & 14.8 & 9.89 & $\begin{array}{c}\text { Not } \\
\text { availabl } \\
\text { e }\end{array}$ & No & No \\
\hline
\end{tabular}




\begin{tabular}{|c|c|c|c|c|c|c|c|c|c|c|c|c|c|c|c|c|c|}
\hline 16 & Diabetes & Yes & \multicolumn{4}{|c|}{ No sample available } & 4 & No & 10 & 79,83 & 18 & 28,1 & 3,4 & 4,26 & $\begin{array}{c}\text { Not } \\
\text { availabl } \\
\text { e }\end{array}$ & No & No \\
\hline 17 & None & Yes & 101.3 & 34.3 & 0.18 & 0.17 & 0 & No & 57 & 170.4 & 10.2 & 19.7 & 13.27 & 7.7 & $\begin{array}{c}<40 \\
\mu \mathrm{mol} / \mathrm{g}\end{array}$ & $\begin{array}{l}\text { Iron } \\
\text { overloa } \\
\quad d\end{array}$ & $\begin{array}{l}\text { Hypertension, } \\
\text { Diabetes, } \\
\text { Dylipidemia }\end{array}$ \\
\hline 18 & $\begin{array}{c}\text { Arthropathy, } \\
\text { diabetes }\end{array}$ & Yes & 91.3 & 52.0 & 7.35 & 8.05 & 2 & No & 123 & 17.3 & 6.14 & 12.8 & 0.39 & 2.2 & $\begin{array}{c}<40 \\
\mu \mathrm{mol} / \mathrm{g}\end{array}$ & Normal & $\begin{array}{l}\text { Diabetes, } \\
\text { Hypertension, } \\
\text { Pulmonary fibrosis }\end{array}$ \\
\hline
\end{tabular}


